\title{
Crystalline Ceramic Waste Forms: Report Detailing Data Collection in Support of Potential FY13 Pilot Scale Melter Test
}

Fuel Cycle Research \& Development

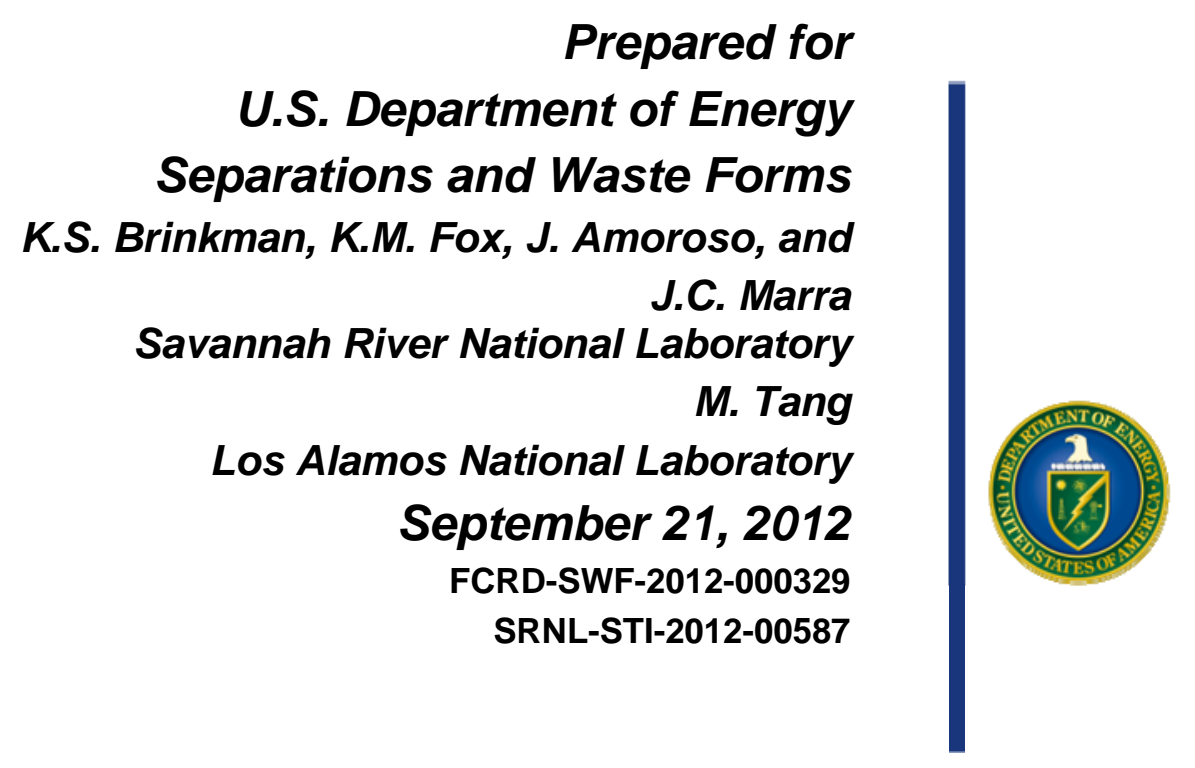


Crystalline Ceramic Waste Forms: Report Detailing Data Collection in Support of Potential FY13 Pilot Scale Melter Test 


\section{DISCLAIMER}

This information was prepared as an account of work sponsored by an agency of the U.S. Government. Neither the U.S. Government nor any agency thereof, nor any of their employees, makes any warranty, expressed or implied, or assumes any legal liability or responsibility for the accuracy, completeness, or usefulness, of any information, apparatus, product, or process disclosed, or represents that its use would not infringe privately owned rights. References herein to any specific commercial product, process, or service by trade name, trade mark, manufacturer, or otherwise, does not necessarily constitute or imply its endorsement, recommendation, or favoring by the U.S. Government or any agency thereof. The views and opinions of authors expressed herein do not necessarily state or reflect those of the U.S. Government or any agency thereof. 


\section{SUMMARY}

The research conducted in this work package is aimed at taking advantage of the long term thermodynamic stability of crystalline ceramics to create more durable waste forms (as compared to high level waste glass) in order to reduce the reliance on engineered and natural barrier systems. Durable ceramic waste forms that incorporate a wide range of radionuclides have the potential to broaden the available disposal options and to lower the storage and disposal costs associated with advanced fuel cycles. Assemblages of several titanate phases have been successfully demonstrated to incorporate radioactive waste elements, and the multiphase nature of these materials allows them to accommodate variation in the waste composition. Recent work has shown that they can be successfully produced from a melting and crystallization process. The objective of this report is to summarize the data collection in support of future melter demonstration testing for crystalline ceramic waste forms.

The waste stream used as the basis for the development and testing is a combination of the projected $\mathrm{Cs} / \mathrm{Sr}$ separated stream, the Trivalent Actinide - Lanthanide Separation by Phosphorous reagent Extraction from Aqueous Komplexes (TALSPEAK) waste stream consisting of lanthanide fission products, the transition metal fission product waste stream resulting from the transuranic extraction (TRUEX) process, and a high molybdenum concentration with relatively low noble metal concentrations.

The principal difficulties encountered during processing of the "reference ceramic" waste form by a melt and crystallization process were the incomplete incorporation of Cs into the hollandite phase and the presence of secondary Cs-Mo non-durable phases. In the single phase hollandite system, these issues were addressed in this study by refining the compositions to include $\mathrm{Cr}$ as a transition metal element and the use of $\mathrm{Ti} / \mathrm{TiO}_{2}$ buffer to maintain reducing conditions. Initial viscosity studies of ceramic waste forms indicated that the pour spout must be maintained above $1400^{\circ} \mathrm{C}$ to avoid flow blockages due to crystallization. In-situ electron irradiations simulate radiolysis effects indicated hollandite undergoes a crystalline to amorphous transition after a radiation dose of $10^{13}$ Gy which corresponds to approximately 1000 years at anticipated doses $\left(2 \times 10^{10}-2 \times 10^{11} \mathrm{~Gy}\right)$. Dual-beam ion irradiations employing light ion beam (such as $5 \mathrm{MeV}$ alpha) and heavy ion beam (such as $100 \mathrm{keV} \mathrm{Kr}$ ) studies indicate that reference ceramic waste forms are radiation tolerant to the $\beta$-particles and $\alpha$-particles, but are susceptible to a crystalline to amorphous transition under recoil nuclei effects.

A path forward for refining the processing steps needed to form the targeted phase assemblages is outlined in this report. Processing modifications including melting in a reducing atmosphere with the use of $\mathrm{Ti} / \mathrm{TiO}_{2}$ buffers, and the addition of $\mathrm{Cr}$ to the transition metal additives to facilitate Cs-incorporation in the hollandite phase. In addition to melt processing, alternative fabrication routes are being considered including Spark Plasma Sintering (SPS) and Hot Isostatic Pressing (HIP). 


\section{CONTENTS}

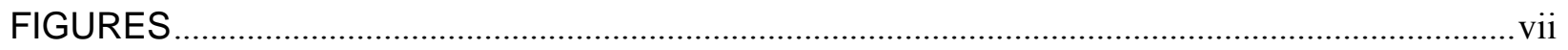

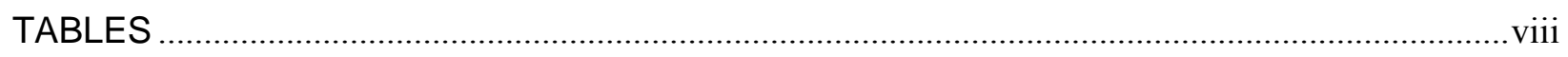

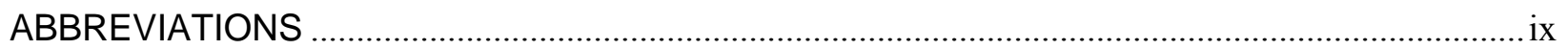

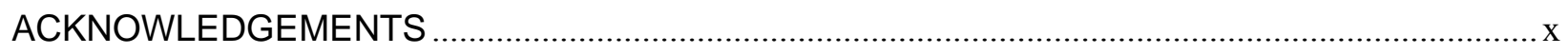

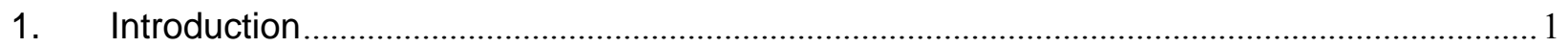

2. Reference Composition-Target vs. Achieved Phase Formation ............................................2

3. Single Phase Hollandite-Composition and Processing ........................................................ 3

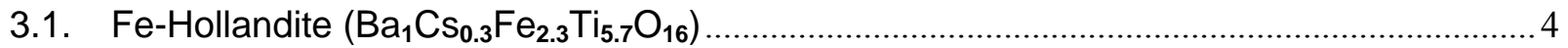

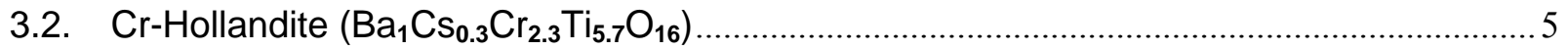

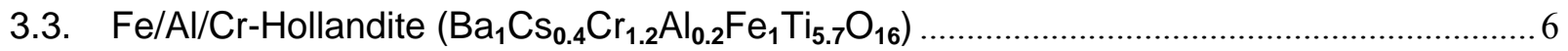

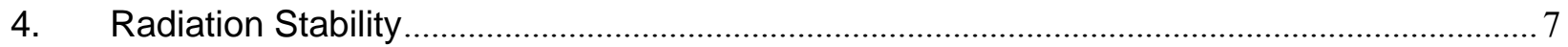

4.1. Electron Irradiation (TEM)- Hollandite ................................................................................... 7

4.2. Dual Beam Studies- Combined Waste Forms …................................................................... 11

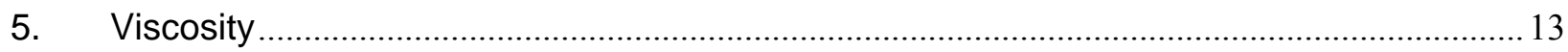

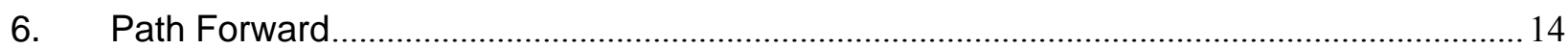

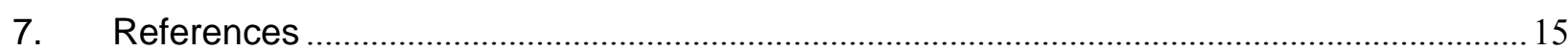

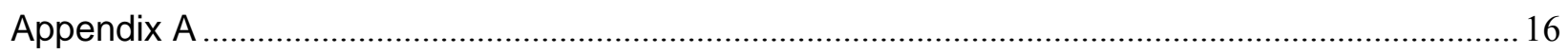




\section{FIGURES}

Figure 2-1. CW-AFHZ Fabricated by a Melting and Crystallizing in a $1 \% \mathrm{H}_{2}$ balance ArgonBackscattered Electron Micrograph

Figure 3-1. Fe-Hollandite $\left(\mathrm{Ba}_{1} \mathrm{Cs}_{0.3} \mathrm{Fe}_{2.3} \mathrm{Ti}_{5.7} \mathrm{O}_{16}\right)$ WITHOUT Ti/TiO ${ }_{2}$ Buffer, Fabricated by Melting and Crystallizing a)TEM Bright Field Image and b) EDS Chemical Composition ................................... 4

Figure 3-2. Fe-Hollandite $\left(\mathrm{Ba}_{1} \mathrm{Cs}_{0.3} \mathrm{Fe}_{2.3} \mathrm{Ti}_{5.7} \mathrm{O}_{16}\right)$ With $\mathrm{Ti} / \mathrm{TiO}_{2}$ Buffer, Fabricated by Melting and Crystallizing a)X-Ray Diffraction Spectra and b) SEM-Backscattered Electron Micrograph .............. 5

Figure 3-3. Cr-Hollandite $\left(\mathrm{Ba}_{1} \mathrm{Cs}_{0.3} \mathrm{Cr}_{2.3} \mathrm{Ti}_{5.7} \mathrm{O}_{16}\right)$ With $\mathrm{Ti} / \mathrm{TiO}_{2}$ Buffer, Fabricated by Melting and Crystallizing a)X-Ray Diffraction Spectra and b) SEM-Backscattered Electron Micrograph.............. 5

Figure 3-4. Fe/Al/Cr-Hollandite $\left(\mathrm{Ba}_{1} \mathrm{Cs}_{0.4} \mathrm{Cr}_{1.2} \mathrm{Al}_{0.2} \mathrm{Fe}_{1} \mathrm{Ti}_{5.7} \mathrm{O}_{16}\right)$ With $\mathrm{Ti} / \mathrm{TiO}_{2}$ Buffer, Fabricated by Melting and Crystallizing a)X-Ray Diffraction Spectra and b) SEM-Backscattered Electron Micrograph ......

Figure 3-5. Fe/Al/Cr-Hollandite $\left(\mathrm{Ba}_{1} \mathrm{Cs}_{0.4} \mathrm{Cr}_{1.2} \mathrm{Al}_{0.2} \mathrm{Fe}_{1} \mathrm{Ti}_{5.7} \mathrm{O}_{16}\right)$ With $\mathrm{Ti} / \mathrm{TiO}_{2}$ Buffer, Fabricated by Melting and Crystallizing SEM-Backscattered Electron Micrograph and Energy Dispersive Spectroscopy (EDAX) at Different Grain Locations......

Figure 4-1. Fe-Hollandite (WITHOUT Ti/ $\mathrm{TiO}_{2}$ additions) High-Resolution TEM Images Reveal Change to the Crystalline Structure of the Hollandite Phase Following Electron Irradiation at the Level of $10^{13}$ Gy.

Figure 4-2. Al-Hollandite-( $\left.\mathrm{Ba}_{1} \mathrm{Cs}_{0.2} \mathrm{Al}_{2.3} \mathrm{Ti}_{5.7} \mathrm{O}_{16}\right)$ TEM/EDX WITHOUT Ti/TiO ${ }_{2}$ Buffer, Fabricated by Melting and Crystallizing a)TEM Bright Field Image and b) EDS Chemical Composition.

Figure 4-3. Al-Hollandite- High-Resolution TEM Images Reveal Change to the Crystalline Structure of the Hollandite Phase Following Electron Irradiation at the Level of $10^{13} \mathrm{~Gy}$.

Figure 4-4. $\mathrm{Al} / \mathrm{Fe}-H o l l a n d i t e\left(\mathrm{Ba}_{1} \mathrm{Cs}_{0.28} \mathrm{Al}_{1.46} \mathrm{Fe}_{0.82} \mathrm{Ti}_{5.72} \mathrm{O}_{16}\right)-\mathrm{TEM} / \mathrm{EDX}$ WITHOUT $\mathrm{Ti} / \mathrm{TiO}_{2} \quad \mathrm{Buffer}$ Fabricated by Melting and Crystallizing a)TEM Bright Field Image and b) EDAX Chemical Composition. 10

Figure 4-5. Al/Fe-Hollandite- High-Resolution TEM Images Reveal Change to the Crystalline Structure of the Hollandite Phase Following Electron Irradiation at the Level of $10^{13} \mathrm{~Gy}$. 10

Figure 4-6. CSLNTM-2- Dual Beam Radiation Damage: Before and After 5MeV Alpha and $600 \mathrm{keV} \mathrm{Kr}$ Room Temperature Irradiation.

Figure 4-7. CWAFHZCa100- Dual Beam Radiation Damage: Before and After 2MeV Proton and 600 $\mathrm{keV} \mathrm{Kr}$ Irradiation at Room Temperature. 13

Figure 5-1. Viscosity $(\mathrm{P})$ versus Temperature $\left({ }^{\circ} \mathrm{C}\right)$ for Crystalline Ceramic Waste Form 14 


\section{TABLES}

Table 2-1. Reference Ceramic Composition (wt \%) for CSLNTM-High Mo Waste Streams. ..................2

Table 2-2. CW-AFHZ Fabricated by Melting and Crystallizing in $1 \% \mathrm{H}_{2}$ balance Argon-Summary of Elements and Crystalline Phases (*Crystalline phases determined from XRD measurements and EDAX elemental analysis)

Table 4-1. Targeted Compositions (wt \%) for the Ceramic Waste Forms used in Dual Beam Irradiation Studies. 


\section{ABBREVIATIONS}

AFCI Advanced Fuel Cycle Initiative

CCIM Cold Crucible Induction Melter

CS Cesium/Strontium

DOE Department of Energy

EDAX Energy Dispersive Spectroscopy

FCR\&D Fuel Cycle Research and Development

HLW High Level Waste

LANL Los Alamos National Laboratory

LN Lanthanides

NM Noble Metals

PCT Product Consistency Test

PUREX Plutonium, Uranium, Extraction Processes

Redox Reduction/Oxidation

SEM Scanning Electron Microscopy

SRNL Savannah River National Laboratory

SYNROC Titanium based ceramic substance that can incorporate nuclear waste

TALSPEAK Trivalent Actinide - Lanthanide Separation by Phosphorous reagent Extraction from Aqueous Komplexes

TEM Transmission Electron Microscopy

TM Transition Metals

TRUEX Transuranic Extraction

XRD X-ray Diffraction 


\section{ACKNOWLEDGEMENTS}

The authors would like to thank Henry Ajo, David Best, David Missimer, Phyllis Workman, Pat Simmons, Whitney Riley, Mark Jones, and Curtis Johnson of SRNL for their assistance with sample preparation and characterization.

\section{Government License Notice}

This work was prepared under an agreement with and funded by the U.S. Government. Neither the U. S. Government or its employees, nor any of its contractors, subcontractors or their employees, makes any express or implied: 1. warranty or assumes any legal liability for the accuracy, completeness, or for the use or results of such use of any information, product, or process disclosed; or 2. representation that such use or results of such use would not infringe privately owned rights; or 3. endorsement or recommendation of any specifically identified commercial product, process, or service. Any views and opinions of authors expressed in this work do not necessarily state or reflect those of the United States Government, or its contractors, or subcontractors.

This document has been created by Savannah River Nuclear Solutions, LLC, Operator of Savannah River National Laboratory under Contract No. DE-AC09-08SR22470. The U.S. Government retains for itself, and others acting on its behalf, a paid-up nonexclusive, irrevocable worldwide license in said article to reproduce, prepare derivative works, distribute copies to the public, and perform publicly and display publicly, by or on behalf of the Government.

This work was supported by the U.S. Department of Energy, Office of Nuclear Energy, under Contract DE-AC02-06CH11357. 


\section{Introduction}

The research conducted by the United States Department of Energy (DOE) under the advanced waste forms division of the FCR\&D program is to make the U.S. fuel cycle more effective by developing next generation waste management technologies capable of processing waste material generated from fuel cycle separations for Used Nuclear Fuel (UNF) and from the fabrication of advanced fuels or targets containing materials to be transmuted.[1-3] The research described in this work package was aimed at taking advantage of the long term thermodynamic stability of crystalline ceramics to create more durable waste forms (as compared to high level waste (HLW) glass) in order to broaden the available disposal options and to lower the storage and disposal costs associated with advanced fuel cycles.

Crystalline ceramic waste forms incorporate radionuclides as part of their crystal structure.[4] As such, ceramic waste forms can be tailored (i.e. unique crystalline structures) to host radionuclides by binding them into a specific crystalline network. Ceramic waste forms are tailored based on the knowledge and understanding of naturally occurring minerals containing radioactive and non-radioactive species similar to the radionuclides of concern in wastes from fuel reprocessing.

This report summarizes the data collected in support of future melter demonstration testing for crystalline ceramic waste forms. Detailed progress on processing and composition development of crystalline ceramic waste form materials is detailed in FY10, 11, and 12 reports [5-7]. This report will refine the composition and processing conditions outlined in the recent "Reference Formulation Report for Crystalline Ceramic Waste Forms"[7]. This report will form the basis of subsequent FY13 studies to select a reference ceramic and process technology for the incorporation of i) combined HLW raffinate stream (containing undissolved solids and soluble technetium) and ii) transuranic (TRU) waste stream from fuels fabrication. 


\section{Reference Composition-Target vs. Achieved Phase Formation}

The targeted phase composition for incorporation of the combined $\mathrm{Cs} / \mathrm{Sr}$, lanthanide fission products and transition metal waste stream (CW-AFHZ) is given in Table 2-1 [7]. $\mathrm{Fe}_{2} \mathrm{O}_{3}$ (5.82 wt \%) was used as the baseline additive for improved hollandite formation. An SEM micrograph depicting the microstructure of the reference waste form (CW-AFHZ) melted at $1500^{\circ} \mathrm{C}$ for 20 minutes in a $1 \% \mathrm{H}_{2}$ balance argon atmosphere is shown in Figure 2-1. The targeted hollandite, perovskite, and zirconolite phases were observed along with alumina, powellite, and a Cs-Mo phase. The measured phases and their compositions are summarized in Table 2-2.

Table 2-1. Reference Ceramic Composition (wt \%) for CSLNTM-High Mo Waste Streams.

*Fe or multivalent transition metal (Co, $\mathrm{Zn}, \mathrm{Cr})$ to assist hollandite formation [8, 9]

\begin{tabular}{|c|c|c|}
\hline Composition & wt \% & Targeted Phase \\
\hline Waste & 23.74 & \\
\hline$\overline{\mathrm{Al}_{2} \mathrm{O}_{3}}$ & 6.62 & Hollandite \\
\hline $\mathrm{TiO}_{2}$ & 51.03 & $\begin{array}{c}\text { Hollandite, Perovskite, } \\
\text { Zirconolite }\end{array}$ \\
\hline $\mathrm{CaO}$ & 1.36 & Zirconolite \\
\hline $\mathrm{BaO}$ & 11.43 & Hollandite \\
\hline$* \mathrm{Fe}_{2} \mathrm{O}_{3}$ & 5.82 & Hollandite \\
\hline
\end{tabular}

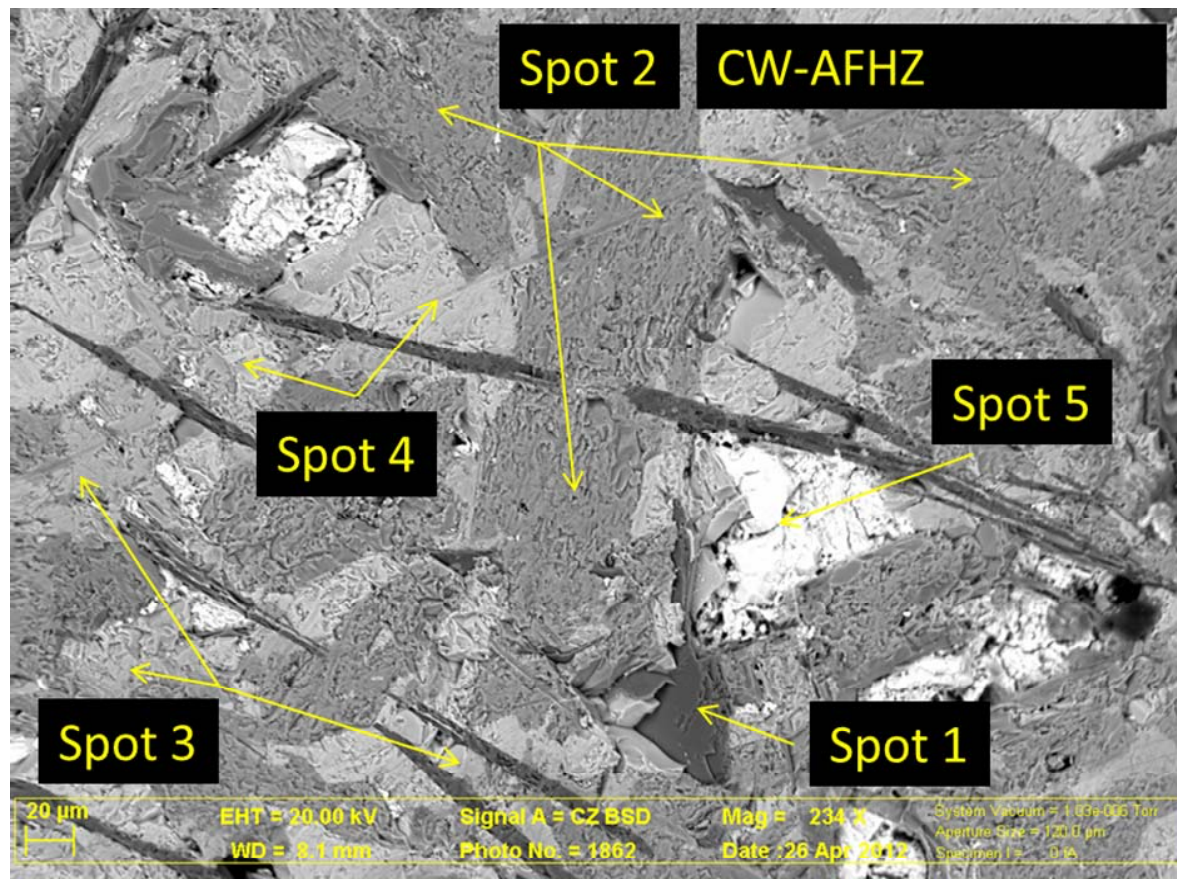

Figure 2-1. CW-AFHZ Fabricated by a Melting and Crystallizing in a $1 \% \mathrm{H}_{2}$ balance ArgonBackscattered Electron Micrograph 
Table 2-2. CW-AFHZ Fabricated by Melting and Crystallizing in $1 \% \mathrm{H}_{2}$ balance Argon-Summary of Elements and Crystalline Phases (*Crystalline phases determined from XRD measurements and EDAX elemental analysis)

\begin{tabular}{|c|l|l||}
\hline Spot & Elements (Major, Minor) & \multicolumn{1}{c|}{ Crystalline Phases* } \\
\hline 1 & $\mathrm{O}, \mathrm{Al}$ & $\mathrm{Al}_{2} \mathrm{O}_{3}$ \\
\hline 2 & $\mathrm{O}, \mathrm{Ti}, \mathrm{Al}, \mathrm{Ba}$ & ${\mathrm{Hollandite-} \mathrm{BaAlTi}_{5} \mathrm{O}_{14}}$ \\
\hline 3 & $\mathrm{O}, \mathrm{Ti}, \mathrm{Zr}, \mathrm{Ca}$ & Zirconolite-CaZrTi \\
2 & $\mathrm{O}_{7}$ \\
\hline 4 & $\mathrm{O}, \mathrm{Ti}, \mathrm{Ca}, \mathrm{Nd}$ & Perovskite- $\mathrm{Nd}$ doped $\mathrm{CaTiO}_{3}$ \\
\hline 5 & $\mathrm{O}, \mathrm{Cs}, \mathrm{Mo}, \mathrm{Ca}, \mathrm{Ba}$ & $\mathrm{Cs}_{2} \mathrm{MoO}_{4}+(\mathrm{BaCa}) \mathrm{MoO}_{4}$ \\
\hline
\end{tabular}

The successful demonstration of melt processing of ceramic waste forms achieving the targeted phases has been accomplished, however there were additional crystalline phases observed that possessed low durability, specifically the alkali molybdate phases. This is being addressed by varying the transition metal elements in the hollandite structure [9] to facilitate Cs incorporation into the hollandite structure to minimize secondary Cs-Mo phase formation and continued processing in reducing conditions using metal/metal oxide buffers such as $\mathrm{Ti} / \mathrm{TiO}_{2}[10]$.

\section{Single Phase Hollandite-Composition and Processing}

Hollandite derived ceramic waste forms for immobilization of Cs have been previously melted in air using $\mathrm{Cr}, \mathrm{Ni}, \mathrm{Zn}$ or $\mathrm{Co}$ transition metal substitutions resulting in PCT-B normalized leachate concentrations below $0.2 \mathrm{~g} / \mathrm{L}[9]$. The present study used melt processing in air to fabricate three single phase hollandite ceramics with the following stoichiometries:

i) Fe-Hollandite $\left(\mathrm{Ba}_{1} \mathrm{Cs}_{0.3} \mathrm{Fe}_{2.3} \mathrm{Ti}_{5.7} \mathrm{O}_{16}\right)$,

ii) Cr-Hollandite $\left(\mathrm{Ba}_{1} \mathrm{Cs}_{0.3} \mathrm{Cr}_{2.3} \mathrm{Ti}_{5.7} \mathrm{O}_{16}\right)$, and

iii) $\quad \mathrm{Fe} / \mathrm{Al} / \mathrm{Cr}-\mathrm{Hollandite}\left(\mathrm{Ba}_{1} \mathrm{Cs}_{0.4} \mathrm{Cr}_{1.2} \mathrm{Al}_{0.2} \mathrm{Fe}_{1} \mathrm{Ti}_{5.7} \mathrm{O}_{16}\right)$.

The Fe-Hollandite sample was used as a baseline composition from which to compare phase formation and $\mathrm{Cs}$ incorporation. The $\mathrm{Cr}-$ and $\mathrm{Fe} / \mathrm{Al} / \mathrm{Cr}$ - Hollandite samples were designed to promote single phase hollandite formation while simultaneously suppressing undesirable secondary phases.

In addition to compositional variants, all samples were processed with excess Ti metal and $\mathrm{TiO}_{2}$ (referred to in this text as $\mathrm{Ti} / \mathrm{TiO}_{2}$ buffer). The Ti metal was added $-<230$ mesh, $\sim 2.0 \mathrm{wt}$. $\%$ - to control the RedOx state during processing and in effect, phase formation. $\mathrm{TiO}_{2}$ was added $-\sim 6.5$ wt. $\%-$ to buffer the reducing effects of the $\mathrm{Ti}$ metal on $\mathrm{TiO}_{2}$. Ti metal is expected to have a localized effect as it reacts with the batch, reducing $\mathrm{TiO}_{2}\left(\mathrm{Ti}^{+4}\right)$ to $\mathrm{a} \mathrm{Ti}_{2} \mathrm{O}_{3}\left(\mathrm{Ti}^{+3}\right)$ and is also oxidized to $\mathrm{Ti}_{2} \mathrm{O}_{3}\left(\mathrm{Ti}^{+3}\right)$. The reduction of $\mathrm{Ti}^{+4}$ to $\mathrm{Ti}^{+3}$ promotes hollandite formation (requiring multivalent $\mathrm{B}$ site species) and the oxygen partial pressure controlled by the $\mathrm{Ti}^{+4} \rightarrow \mathrm{Ti}^{+3}$ equilibrium maintains the overall melt conditions in a reducing regime. However, if Ti metal is added to a stoichiometric composition of hollandite, it is known to drive the material off composition by consuming $\mathrm{TiO}_{2}\left(\mathrm{Ti}^{4+}\right)$ [11]. Therefore, excess $\mathrm{TiO}_{2}$ was added and anticipated as a minor phase in the single phase hollandite after synthesis.

All compositions were batched and melted in air by direct insertion of samples into a preheated furnace at $1500^{\circ} \mathrm{C}$ and $1600^{\circ} \mathrm{C}$, held for 20 minutes at temperature, and crystallized by furnace cooling. 


\subsection{Fe-Hollandite $\left(\mathrm{Ba}_{1} \mathrm{Cs}_{0.3} \mathrm{Fe}_{2.3} \mathrm{Ti}_{5.7} \mathrm{O}_{16}\right)$}

Figure 3-1 shows the microstructure and chemical composition of Fe-Hollandite prepared without the addition of a $\mathrm{Ti} / \mathrm{TiO}_{2}$ buffer. The grains investigated exhibited the hollandite structure but, none of the examined grains contained appreciable amount of Cs. The sample displayed in Figure 3-1 was electron irradiated and shows evidence of areas that were rendered amorphous. Energy Dispersive Spectroscopy (EDAX) chemical composition did not show any difference in chemical composition between amorphous and crystalline areas of the sample. The X-ray diffraction spectra (not shown) indicated a single phase material with the general hollandite structure $\left(\mathrm{Ba}_{1.14} \mathrm{Fe}_{2.28} \mathrm{Ti}_{5.7} \mathrm{O}_{16}\right)$.

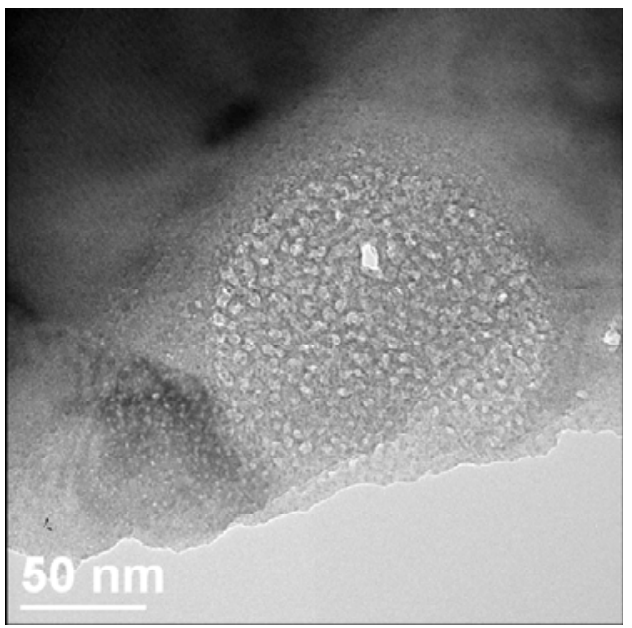

a)

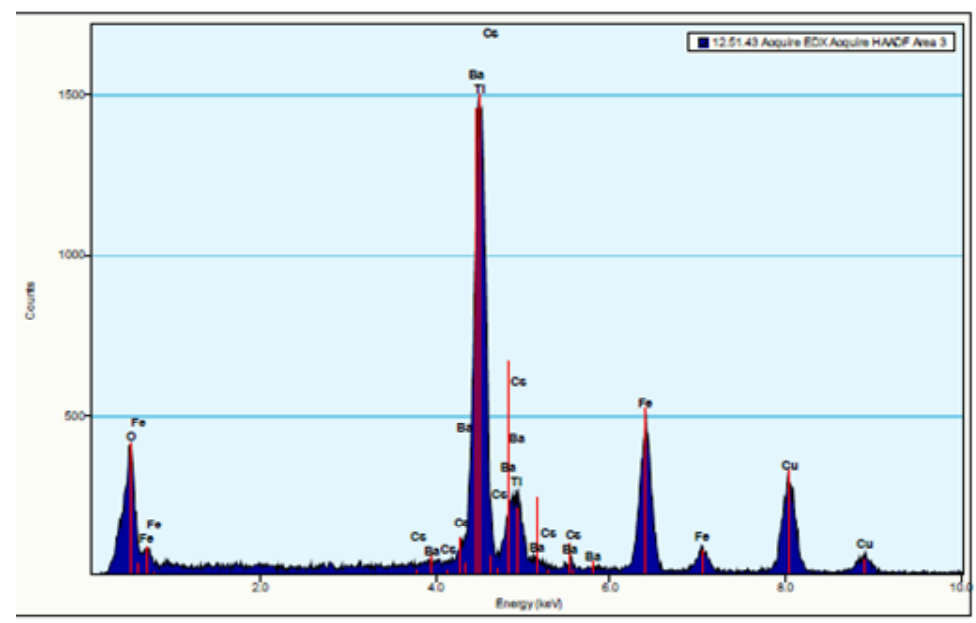

b)

Figure 3-1. Fe-Hollandite $\left(\mathrm{Ba}_{1} \mathrm{Cs}_{0.3} \mathrm{Fe}_{2.3} \mathrm{Ti}_{5.7} \mathrm{O}_{16}\right)$ WITHOUT Ti/TiO ${ }_{2}$ Buffer, Fabricated by Melting and Crystallizing a)TEM Bright Field Image and b) EDS Chemical Composition

The reducing conditions induced by the excess $\mathrm{Ti} / \mathrm{TiO}_{2}$ in $\mathrm{Fe}$-Hollandite resulted in a multiphase crystalline assemblage as shown in Figure 3-2. The identified phases were hollandite $\left(\mathrm{Ba}_{1.2} \mathrm{Cs}_{0.28} \mathrm{Fe}_{0.82} \mathrm{Al}_{1.46} \mathrm{Ti}_{5.72} \mathrm{O}_{16}\right), \mathrm{Fe}_{3} \mathrm{Ti}_{3} \mathrm{O}_{10}$ and $\mathrm{CsAlTiO}_{4}$. The EDAX chemical composition revealed grains with different hollandite compositions, some containing $\mathrm{Cs}$ and some without Cs present along with a secondary Cs-Al-Ti phase. A comparison of Fe-Hollandite with and without excess $\mathrm{Ti} / \mathrm{TiO}_{2}$ indicated that reducing conditions seemed effective for promoting $\mathrm{Cs}$ incorporation into the hollandite phase. However, inhomogeneity and non-durable Cs-Al-Ti phases were also observed. Further studies are needed to understand the magnitude of composition, chemical equilibrium, and melt and crystallization processing effects on phase formation. 


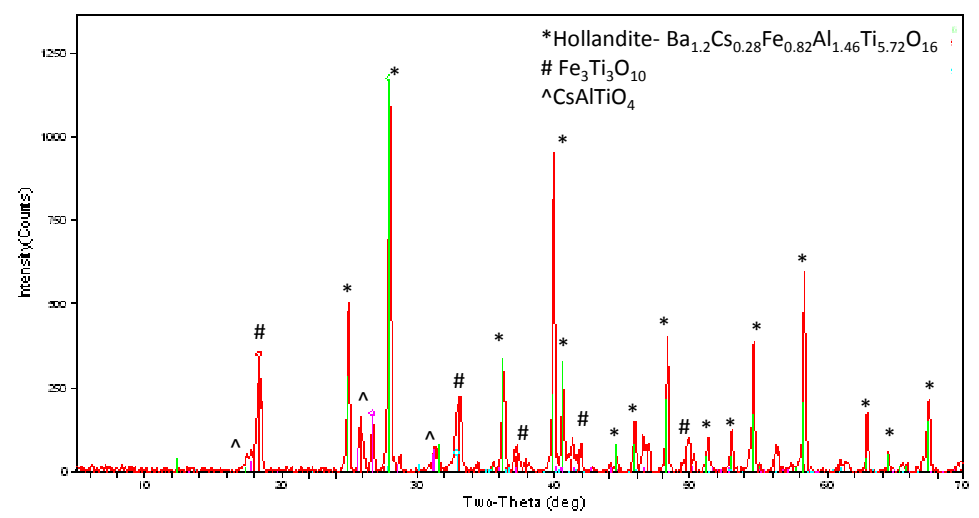

a)

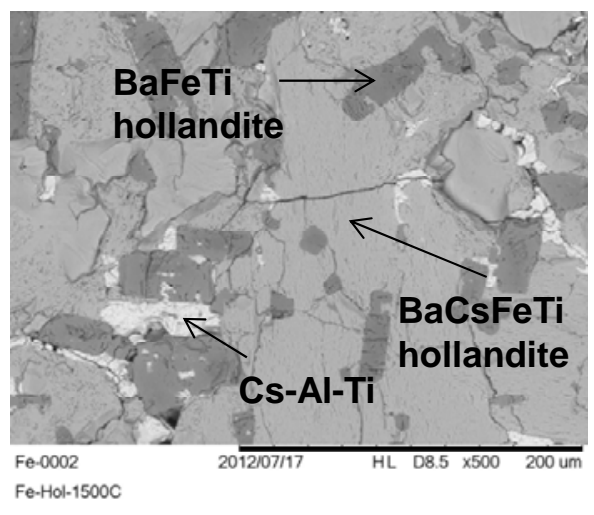

b)

Figure 3-2. Fe-Hollandite $\left(\mathrm{Ba}_{1} \mathrm{Cs}_{0.3} \mathrm{Fe}_{2.3} \mathrm{Ti}_{5.7} \mathrm{O}_{16}\right)$ With Ti/TiO $\mathrm{Buffer}_{2}$ Fabricated by Melting and Crystallizing a)X-Ray Diffraction Spectra and b) SEM-Backscattered Electron Micrograph

\subsection{Cr-Hollandite $\left(\mathrm{Ba}_{1} \mathrm{Cs}_{0.3} \mathrm{Cr}_{2.3} \mathrm{Ti}_{5.7} \mathrm{O}_{16}\right)$}

The Cr-Hollandite sample was single phase hollandite with a minor $\mathrm{TiO}_{2}$ phase as confirmed by X-ray diffraction and EDS and shown in Figure 3-3. The chemical composition measured on different grains with EDAX identified changes in local hollandite stoichiometry, however Cs was always observed in appreciable quantities. The $\mathrm{Cs} / \mathrm{Ba}$ ratio (atomic percent) was an average of $\sim 0.5$ in the areas examined which compares well with the stoichiometric value of 0.3 in $\mathrm{Cr}$-Hollandite $\left(\mathrm{Ba}_{1} \mathrm{Cs}_{0.3} \mathrm{Cr}_{2.3} \mathrm{Ti}_{5.7} \mathrm{O}_{16}\right)$.

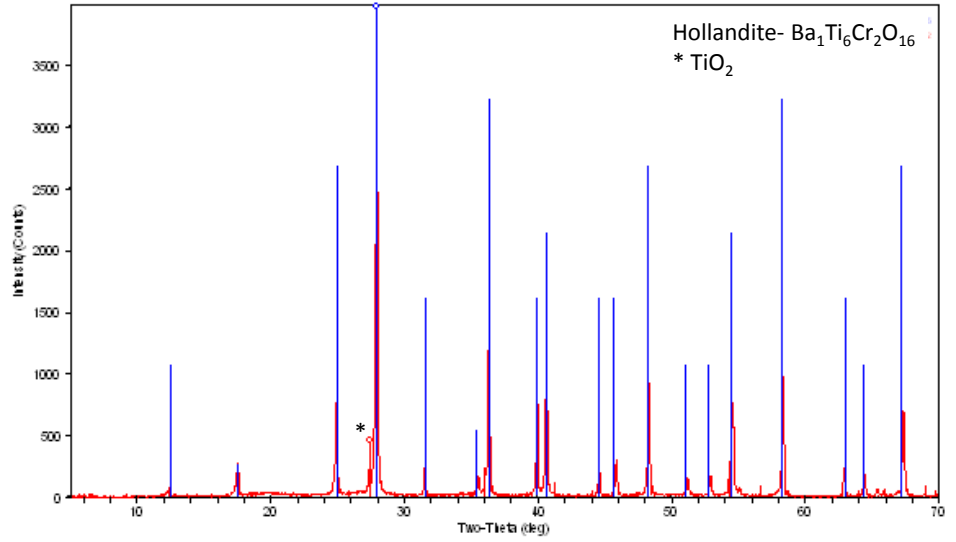

a)

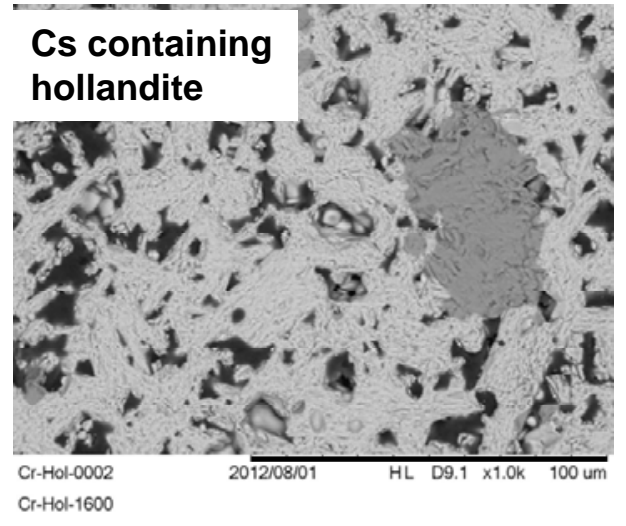

b)

Figure 3-3. Cr-Hollandite $\left(\mathrm{Ba}_{1} \mathrm{Cs}_{0.3} \mathrm{Cr}_{2.3} \mathrm{Ti}_{5.7} \mathrm{O}_{16}\right)$ With Ti/TiO ${ }_{2}$ Buffer, Fabricated by Melting and Crystallizing a)X-Ray Diffraction Spectra and b) SEM-Backscattered Electron Micrograph 


\subsection{FelAl/Cr-Hollandite $\left(\mathrm{Ba}_{1} \mathrm{Cs}_{0.4} \mathrm{Cr}_{1.2} \mathrm{Al}_{0.2} \mathrm{Fe}_{1} \mathrm{Ti}_{5.7} \mathrm{O}_{16}\right)$}

The Fe/Al/Cr-Hollandite sample was single phase Cs-Hollandite as confirmed by XRD and EDAX and shown in Figure 3-4 and Figure 3-5. The chemical composition measured across different grains identified changes in local composition and although different grains appeared to have different hollandite compositions - with and without $\mathrm{Cs}$ - within a given grain, the compositional variation was small.

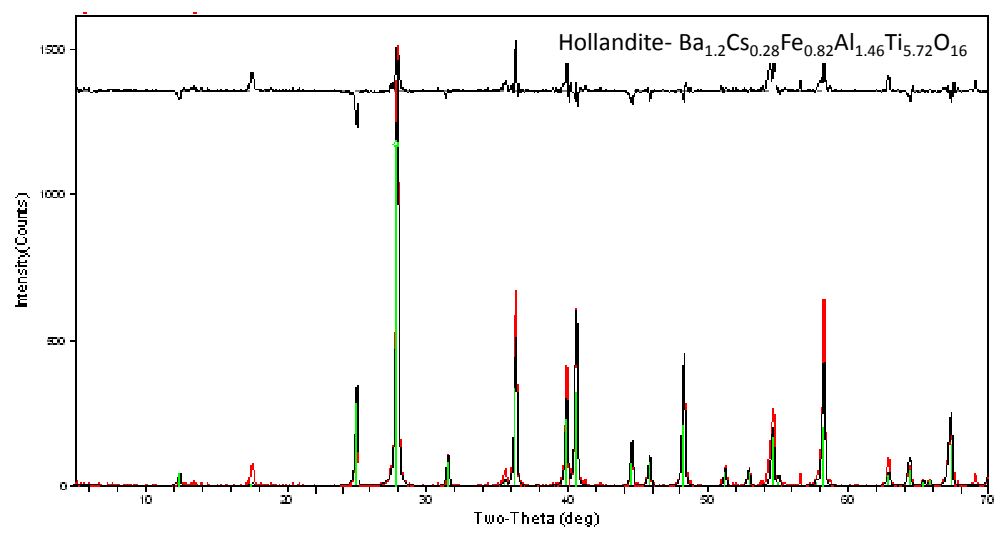

a)

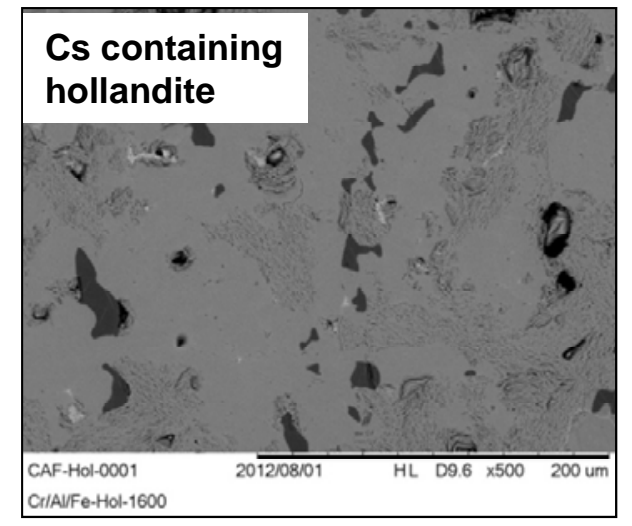

b)

Figure 3-4. $\mathrm{Fe} / \mathrm{Al} / \mathrm{Cr}$-Hollandite $\left(\mathrm{Ba}_{1} \mathrm{Cs}_{0.4} \mathrm{Cr}_{1.2} \mathrm{Al}_{0.2} \mathrm{Fe}_{1} \mathrm{Ti}_{5.7} \mathrm{O}_{16}\right)$ With Ti/TiO $\mathrm{Buffer}$ Fabricated by Melting and Crystallizing a)X-Ray Diffraction Spectra and b) SEM-Backscattered Electron Micrograph
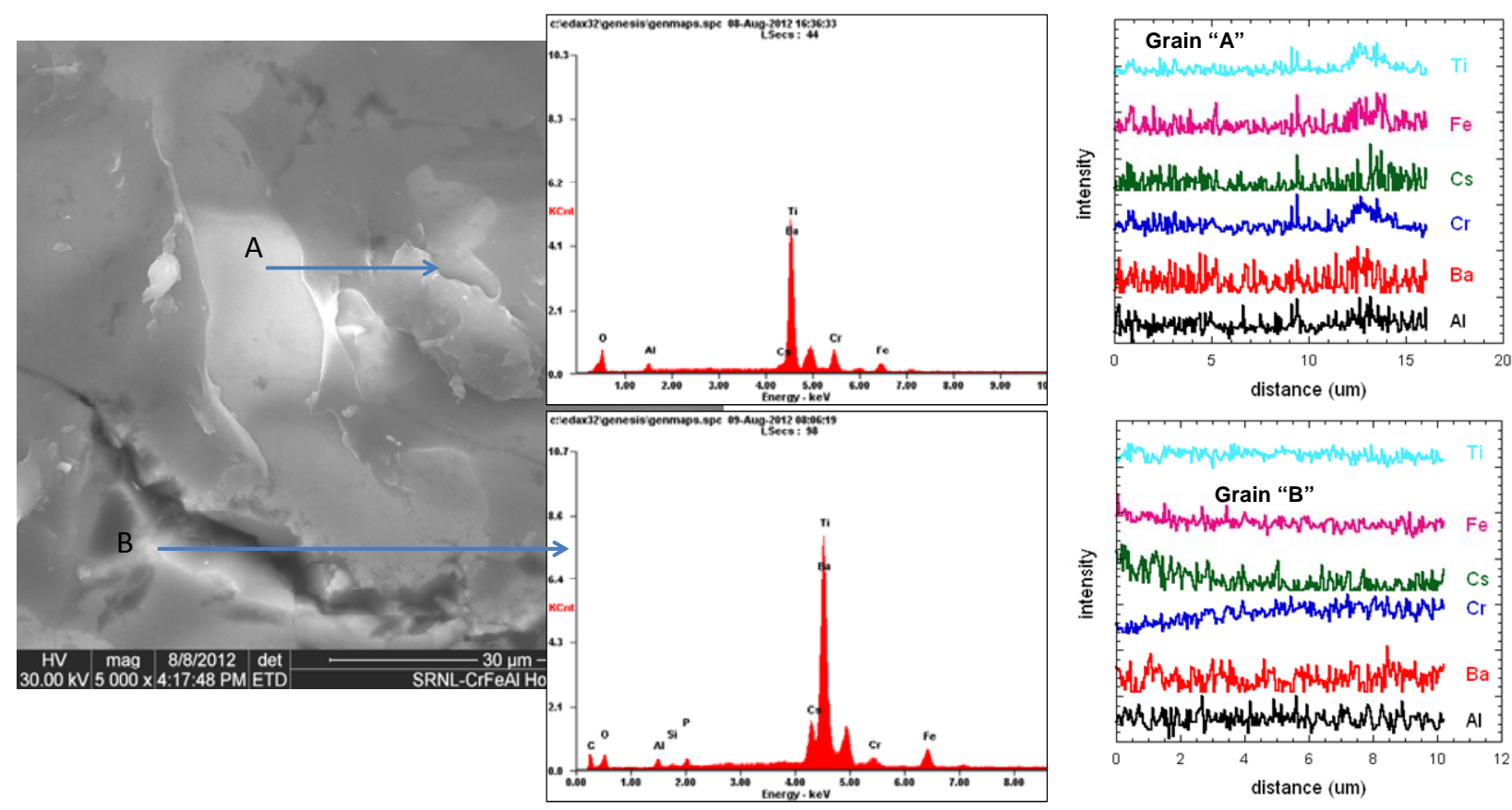

Figure 3-5. Fe/Al/Cr-Hollandite $\left(\mathrm{Ba}_{1} \mathrm{Cs}_{0.4} \mathrm{Cr}_{1.2} \mathrm{Al}_{0.2} \mathrm{Fe}_{1} \mathrm{Ti}_{5.7} \mathrm{O}_{16}\right)$ With Ti/TiO $\mathrm{Buffer}$ Fabricated by Melting and Crystallizing SEM-Backscattered Electron Micrograph and Energy Dispersive Spectroscopy (EDAX) at Different Grain Locations. 
In summary, substituting a portion of the $\mathrm{Fe}$ for $\mathrm{Cr}$ or a combination of $\mathrm{Cr}$ and $\mathrm{Al}$ in the target hollandite composition, along with $\mathrm{Ti} / \mathrm{TiO}_{2}$ buffers, resulted in single phase hollandite formation with the requisite Cs-incorporation. The path forward for this effort includes incorporating $\mathrm{Cr}-\mathrm{Hollandite}$ and $\mathrm{Fe} / \mathrm{Al} / \mathrm{Cr}$ Hollandite into the multiphase waste forms and evaluating phase formation in those more complex systems.

\section{Radiation Stability}

Preliminary evaluations of the radiation damage tolerance of select ceramic waste forms were undertaken by subjecting samples to ion irradiations at LANL. In this study, LANL researchers used dual beam light and heavy ion bombardment, and electron irradiations to simulate the self-radiation damage that occurs in a material incorporating nuclides undergoing radioactive decay. Most of the self-irradiation in a waste form incorporating fission products is due to beta particle and gamma emission. These emissions cause radiation damage primarily via radiolytic processes, because both beta and gamma particles induce substantial electronic excitations in a target material. Light ions and electrons provide a useful means to examine radiolysis effects because they deposit nearly all of their energy in solids via electronic loss processes; and heavy ion are used to simulate energetic recoil nuclei interaction which involves ballistic processes.

\subsection{Electron Irradiation (TEM)- Hollandite}

LANL performed a series of in situ electron irradiations using $300-\mathrm{keV}$ electrons generated in a Tecnai F30 transmission electron microscope (TEM) in the Electron Microscopy Laboratory. By focusing electrons in the TEM on certain crystalline phases of the waste forms, it was possible to simulate radiolysis effects that might be experienced by potential crystalline ceramic waste forms.

Figure 4.1 shows the electron irradiation study for single phase Fe-Hollandite sample. High resolution TEM images and inset fast Fourier transforms (FFT) indicate Fe-Hollandite undergoes a crystalline to amorphous transition after a radiation dose of $10^{13} \mathrm{~Gy}$. The results suggest that this hollandite phase materials exhibit stability to 1000 years at anticipated doses $\left(2 \times 10^{10}-2 \times 10^{11} \mathrm{~Gy}\right)-$ but that their stability may be rate dependent which may limit the activity of the waste for which they can be employed. 


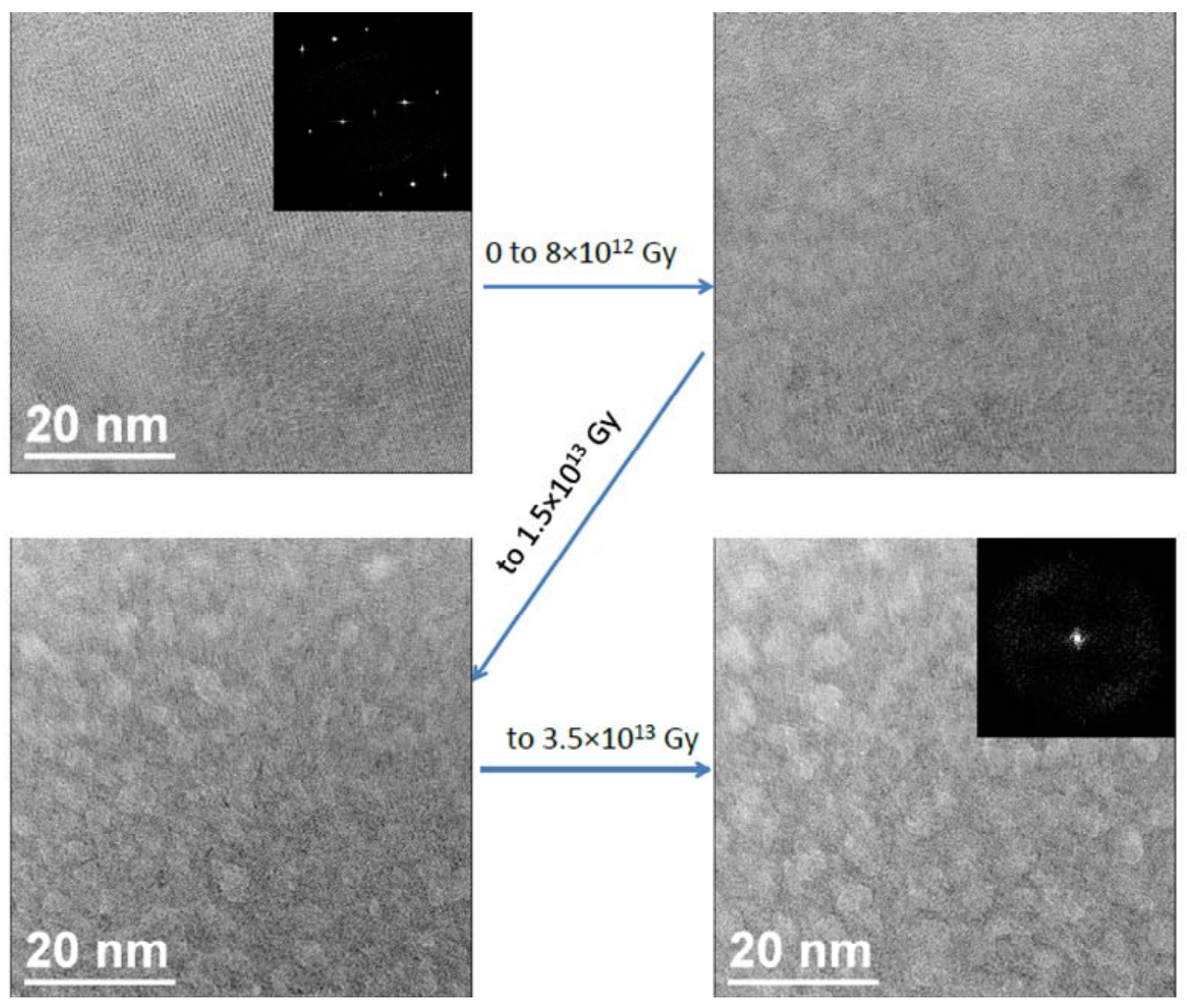

Figure 4-1. Fe-Hollandite (WITHOUT Ti/TiO ${ }_{2}$ additions) High-Resolution TEM Images Reveal Change to the Crystalline Structure of the Hollandite Phase Following Electron Irradiation at the Level of $10^{13} \mathrm{~Gy}$.

An additional hollandite structure was examined to confirm these results. Figure 4-2 shows the TEM determined microstructure and composition from a Al-Hollandite prepared by melt and crystallization process without $\mathrm{Ti} / \mathrm{TiO}_{2}$ buffer additions. Figure 4-3 shows high resolution TEM images indicating changes to the crystalline structure of Al-Hollandite including a crystalline to amorphous transition after a radiation dose of $10^{13} \mathrm{~Gy}$. It is noted that both of the hollandite samples examined above were prepared did not have appreciable quantity of Cs incorporated into the structure.

The impact of Cs containing hollandite was also investigated using an Al/Fe-Hollandite samples presented in Figure 4-4. The bright field TEM and EDAX presented indicate Cs incorporation into the hollandite structure. Figure 4-5 shows high resolution TEM images indicating changes to the crystalline

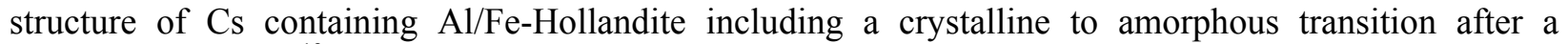
radiation dose of $10^{13} \mathrm{~Gy}$. From these initial studies, it appears that the Cs content has little impact on the radiation stability of the hollandite structure. 


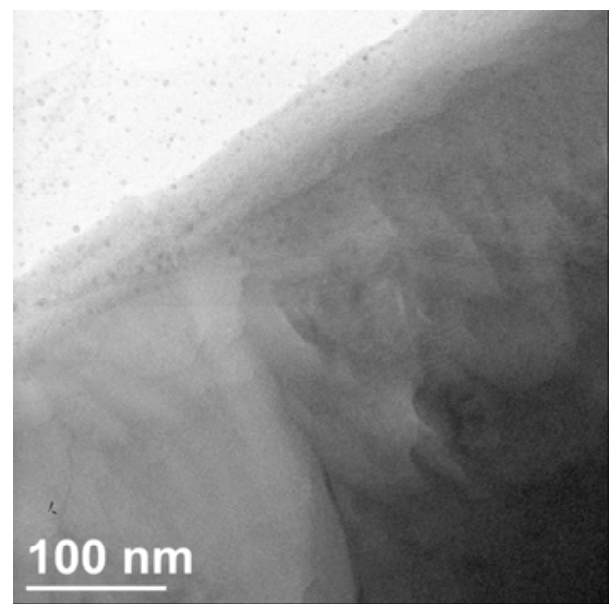

a)

Figure 4-2. Al-Hollandite-( $\left.\mathrm{Ba}_{1} \mathrm{Cs}_{0.2} \mathrm{Al}_{2.3} \mathrm{Ti}_{5.7} \mathrm{O}_{16}\right)$ TEM/EDX WITHOUT Ti/TiO $\mathrm{Buffer}_{2}$ Fabricated by Melting and Crystallizing a)TEM Bright Field Image and b) EDS Chemical Composition

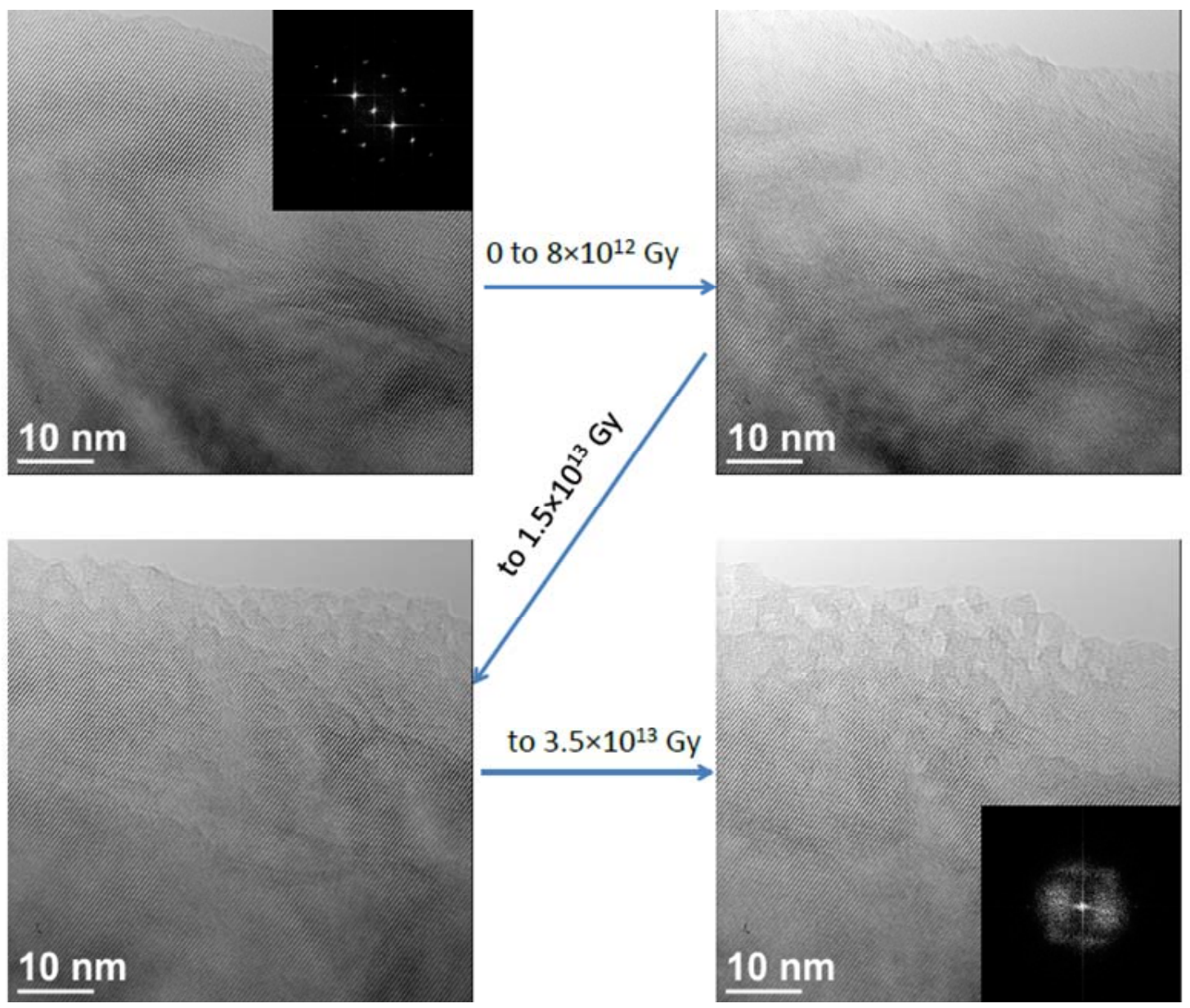

Figure 4-3. Al-Hollandite- High-Resolution TEM Images Reveal Change to the Crystalline Structure of the Hollandite Phase Following Electron Irradiation at the Level of $10^{13} \mathrm{~Gy}$. 


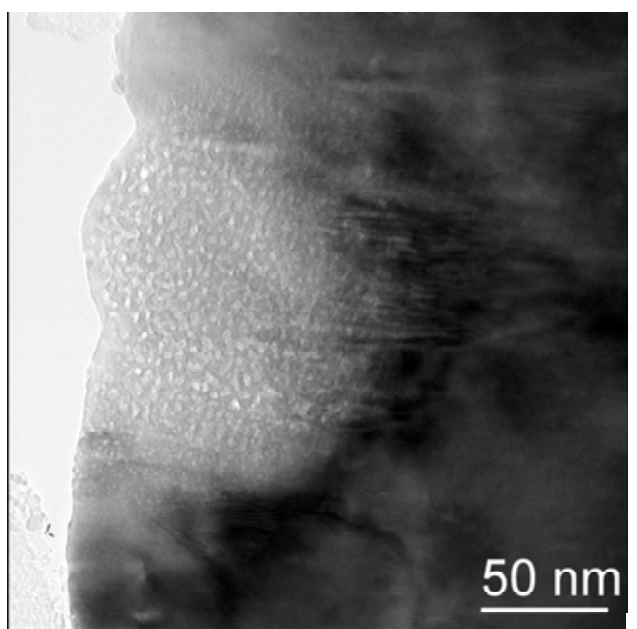

a)

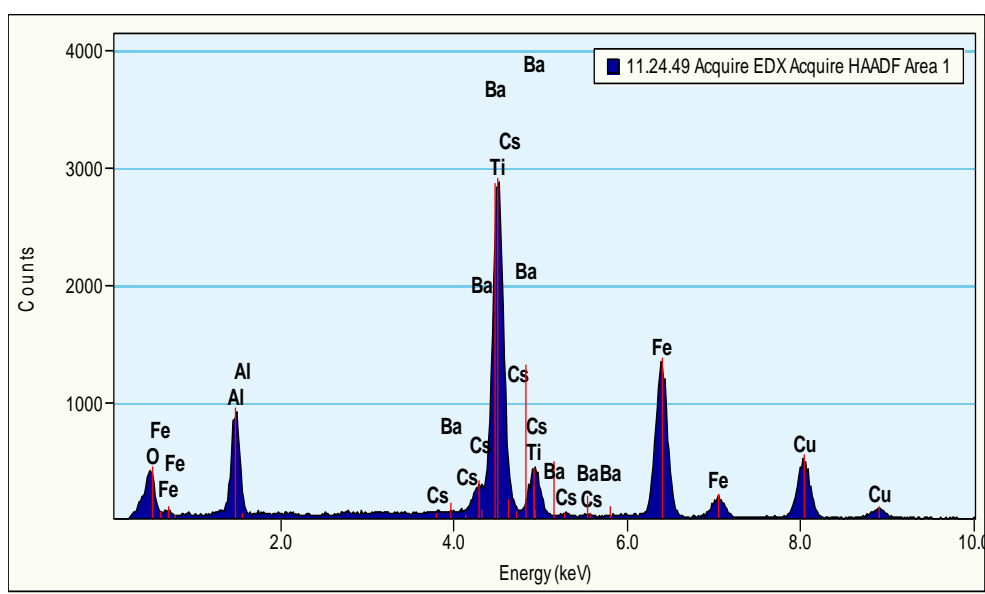

b)

Figure 4-4. Al/Fe-Hollandite $\left(\mathrm{Ba}_{1} \mathrm{Cs}_{0.28} \mathrm{Al}_{1.46} \mathrm{Fe}_{0.82} \mathrm{Ti}_{5.72} \mathrm{O}_{16}\right)$ - TEM/EDX WITHOUT Ti/TiO $\mathrm{Buffer}_{2}$ Fabricated by Melting and Crystallizing a)TEM Bright Field Image and b) EDAX Chemical Composition
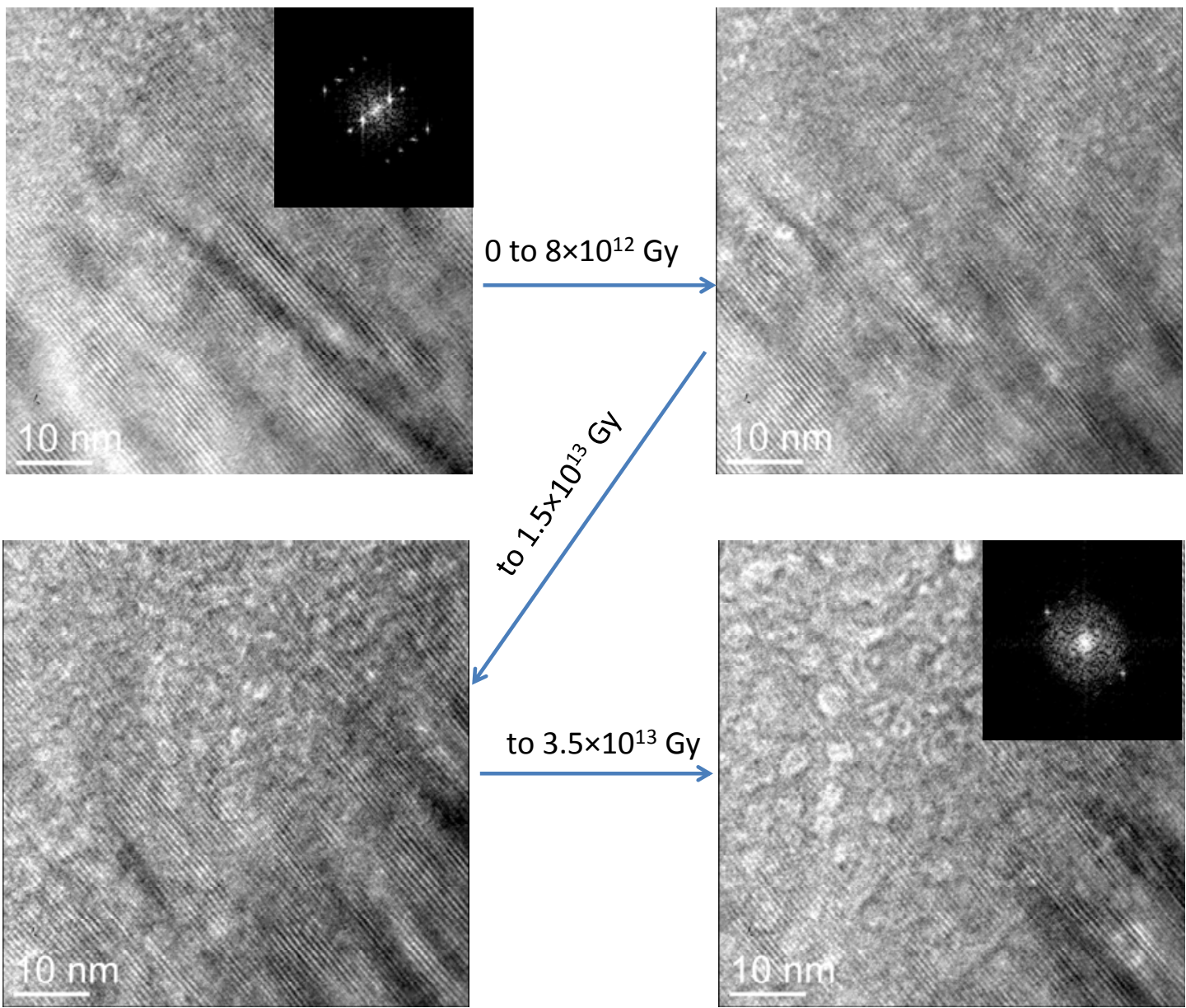

Figure 4-5. Al/Fe-Hollandite- High-Resolution TEM Images Reveal Change to the Crystalline Structure of the Hollandite Phase Following Electron Irradiation at the Level of $10^{13} \mathrm{~Gy}$. 


\subsection{Dual Beam Studies- Combined Waste Forms}

The principal sources of radiation in high-level nuclear wastes (HLW) are $\beta$-decay of the fission products (e.g., 137Cs and 90Sr) and $\alpha$-decay of the actinide elements (e.g., U, Np, Pu, Am, and Cm). Beta-decay produces energetic $\beta$-particles, very low energy recoil nuclei, and $\gamma$-rays, whereas, $\alpha$-decay produces energetic $\alpha$-particles (4.5 to $5.5 \mathrm{MeV}$ ), energetic recoil nuclei (70 to $100 \mathrm{keV}$ ), and some $\gamma$-rays. Beta and alpha decay affect crystalline materials through the interactions of the $\beta$-particles, $\alpha$-particles, recoil nuclei, and $\gamma$-rays with the ceramic phases. These interactions fall into two broad categories: the transfer of energy to electrons (ionization and electronic excitations) and the transfer of energy to atomic nuclei, primarily by ballistic processes involving elastic (billiard-ball-like) collisions.

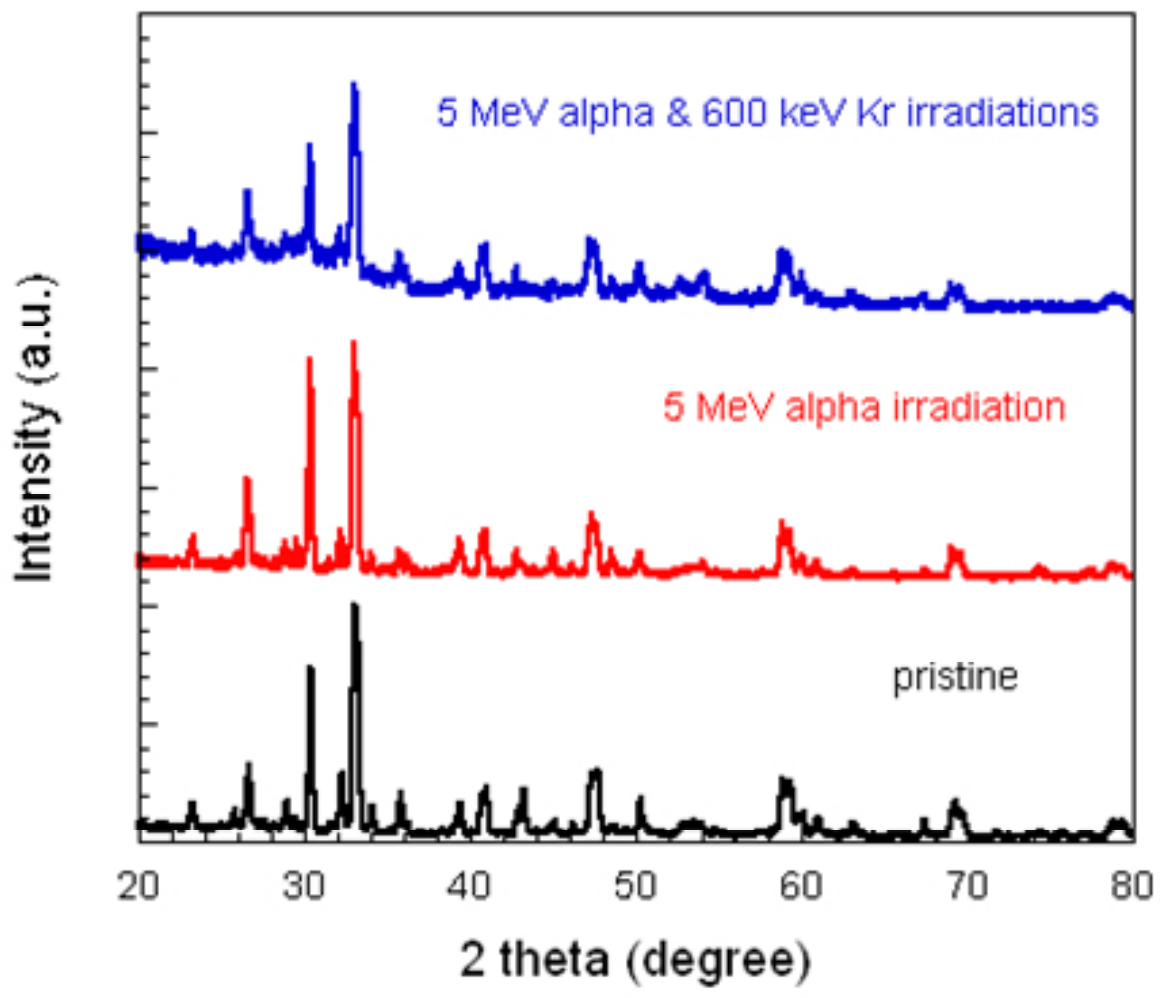

Figure 4-6. CSLNTM-2- Dual Beam Radiation Damage: Before and After 5MeV Alpha and 600 keV Kr Room Temperature Irradiation

Dual-beam ion irradiations capability at IBML provide a useful means to examine radiation stability of advanced nuclear waste forms, because light ion beam (such as $5 \mathrm{MeV}$ alpha) generated by a $3.2 \mathrm{MeV}$ Tandem accelerator could be used to simulate $\alpha$-particles and heavy ion beam (such as $100 \mathrm{keV} \mathrm{Kr}$ ) from ion implanter used to simulate energetic recoil nuclei.

Table 4-1 shows two different ceramic waste form compositions that were investigated by dual-beam irradiation in the present study. CSLNTM-2 was a composition studied in FY11 with high waste loading resulting in perovskite, powellite, and zirconolite phase formation[12]. The CWAFHZCa100 sample was developed in FY12 and more closely resembles the reference ceramic composition with $\mathrm{BaO}$ and $\mathrm{Fe}_{2} \mathrm{O}_{3}$ additions targeting the hollandite phase in addition to perovskite, pyrochlore and zirconolite phases[7]. 
Table 4-1. Targeted Compositions (wt \%) for the Ceramic Waste Forms used in Dual Beam Irradiation Studies.

\begin{tabular}{|c|c|c||}
\hline Composition & CSLNTM-2 & CWAFHZCa100 \\
\hline Waste & 60 & 26 \\
\hline $\mathrm{Al}_{2} \mathrm{O}_{3}$ & 14 & 6 \\
\hline $\mathrm{TiO}_{2}$ & 21 & 47 \\
\hline $\mathrm{CaO}$ & 5 & 5.3 \\
\hline $\mathrm{BaO}$ & - & 10.5 \\
\hline $\mathrm{Fe}_{2} \mathrm{O}_{3}$ & - & 5.2 \\
\hline
\end{tabular}

The CSLNTM-2 sample was subjected to a $5 \mathrm{MeV}$ alpha (He-light ion) beam with a fluence of $1 \times 10^{17}$ ions $/ \mathrm{cm}^{2}$ (corresponding to a dose of 7 GGy) and $600 \mathrm{keV} \mathrm{Kr}$ (heavy ion) with a fluence of $2.5 \times 10^{15}$ ions $/ \mathrm{cm}^{2}$ (corresponding to a dose of $4 \mathrm{dpa}$ ) sequentially at room temperature to provide preliminary insight into the radiation damage tolerance of the ceramic waste form,. The sample was evaluated by XRD before and after irradiation to identify any microstructural changes induced by ion irradiations (Figure 4-6). Under $5 \mathrm{MeV}$ alpha irradiation, there are some differences in relative intensities among the peaks in the spectra but no changes in the phases present are apparent, indicating good radiation damage tolerance. The changes in relative intensity could be due to texturing since the spectra were collected from the polished surface of the sample, rather than crushed powders. After sequential dual beam ion irradiations (5 MeV alpha and $600 \mathrm{keV}$ krypton), XRD measurement shows an apparent broad diffraction feature in the scattering angle $2 \theta=25-35^{\circ}$, attributable to an amorphous structure. It indicates that a phase transformation from crystalline to amorphous occurs upon heavy ion irradiation.

Figure 4-7 shows XRD patterns obtained from a sample of composition CWAFHZCa100 before and after the dual beam irradiation at room temperature, $2 \mathrm{MeV}$ proton (H-light ion) beam with a fluence of $1 \times 10^{18}$ ions $/ \mathrm{cm}^{2}$ (corresponding to a dose of $1 \mathrm{GGy}$ ) and $600 \mathrm{keV} \mathrm{Kr}$ (heavy ion) with a fluence of $2.5 \times 10^{15}$ ions $/ \mathrm{cm}^{2}$ (corresponding to a dose of $4 \mathrm{dpa}$ ) sequentially. Similar as the dual beam irradiated CSLNTM-02 sample, there is little differences in the relative intensities among the peaks in the spectra between the pristine and proton irradiated samples. However, after combined light and heavy ion irradiation damage, the spectra changes significantly the appearance of including several new peaks (near $2 \theta=55^{\circ}$ ) and an increased amorphous regime (near $2 \theta=20-30^{\circ}$ ) not present before irradiation. Overall, these dual beam irradiation results indicate that these crystalline ceramic materials are radiation tolerant to the $\beta$-particles and $\alpha$-particles, but are susceptible to a crystalline to amorphous transition under recoil nuclei effects. 


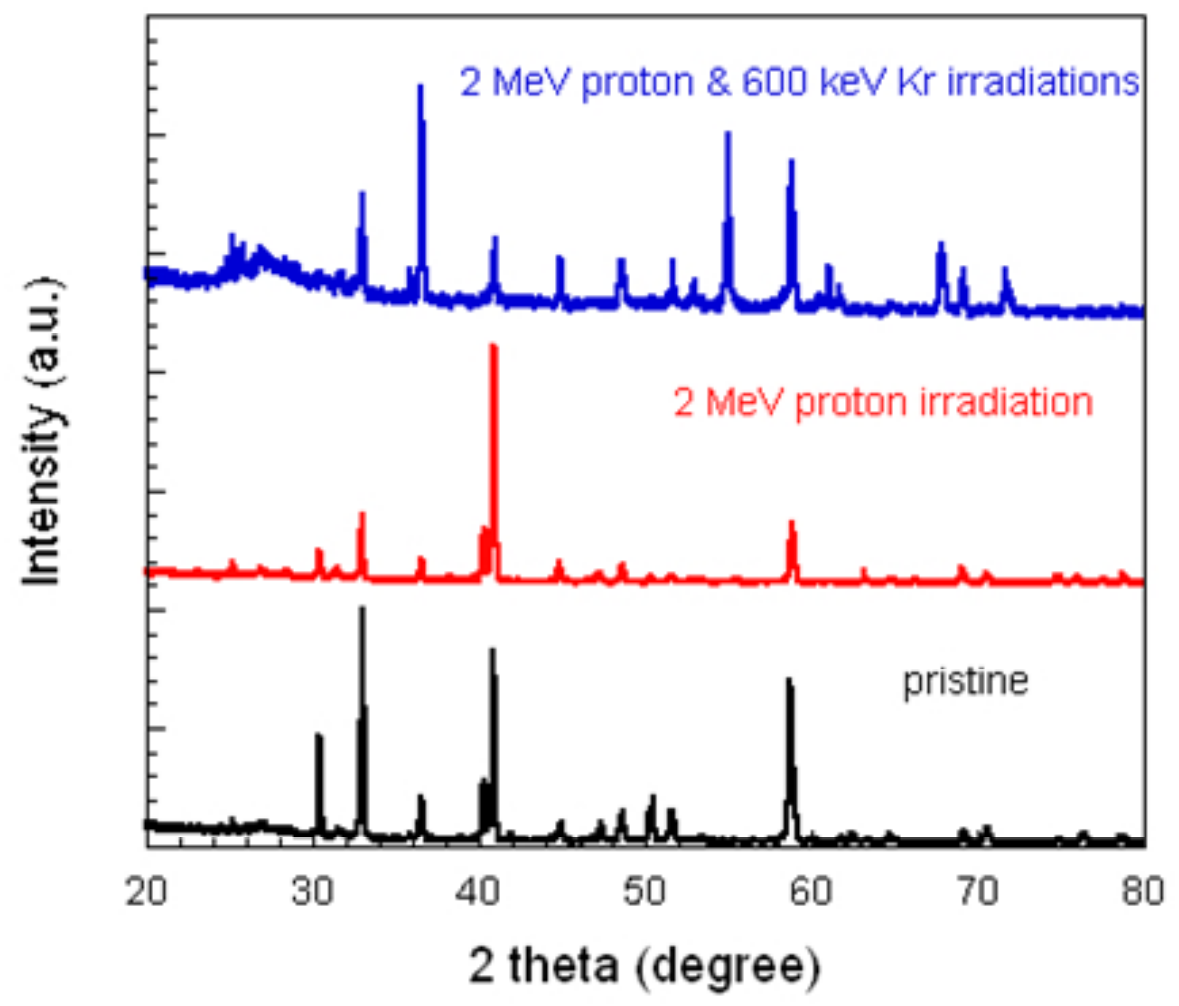

Figure 4-7. CWAFHZCa100- Dual Beam Radiation Damage: Before and After 2MeV Proton and $600 \mathrm{keV}$ Kr Irradiation at Room Temperature

\section{Viscosity}

An examination of the viscosity of crystalline ceramic waste form melts as a function of temperature and composition is especially important when considering industrial scale melt processing. The temperature window where flow will occur as well as the critical temperature where crystallization proceeds must be determined. Figure 5-1 presents the results of initial investigations into the viscosity versus temperature relations for crystalline ceramic waste form melts. A nominal sample composition of CSLNTM-11 was chosen for initial characterization, which closely resembles the reference ceramic composition[7]. A high temperature viscometer was used with a rotating platinum alloy spindle inside a platinum alloy crucible within an electrical resistance heated furnace open to air. The sample was heated to approximately $1500{ }^{\circ} \mathrm{C}$ and the spindle was then lowered into the melt. A viscosity reading was taken after the spindle torque reading stabilized. The sample was then heated to approximately $1550{ }^{\circ} \mathrm{C}$ and a second measurement was taken. Additional measurements were taken after cooling to approximately 1450 and $1400{ }^{\circ} \mathrm{C}$. As shown in Figure 5-1, the melt is very fluid above $1400{ }^{\circ} \mathrm{C}$, with a relatively low viscosity that had little temperature dependence. The melt crystallized rapidly when cooled to between 1350 and $1400{ }^{\circ} \mathrm{C}$, which locked up the viscometer and prevented further measurement. The sample was then reheated to approximately $1500{ }^{\circ} \mathrm{C}$ for a final viscosity measurement. After crystallizing and remelting, there was no change to the measured viscosity value at $1500^{\circ} \mathrm{C}$, as shown in Figure $5-1$. These initial experiments indicate that the pour spout must be maintained above $1400^{\circ} \mathrm{C}$ to avoid flow blockages due to crystallization for this composition. INL is currently modifying their pour spout configuration on the CCIM to address this need as part of their FY13 work scope. 


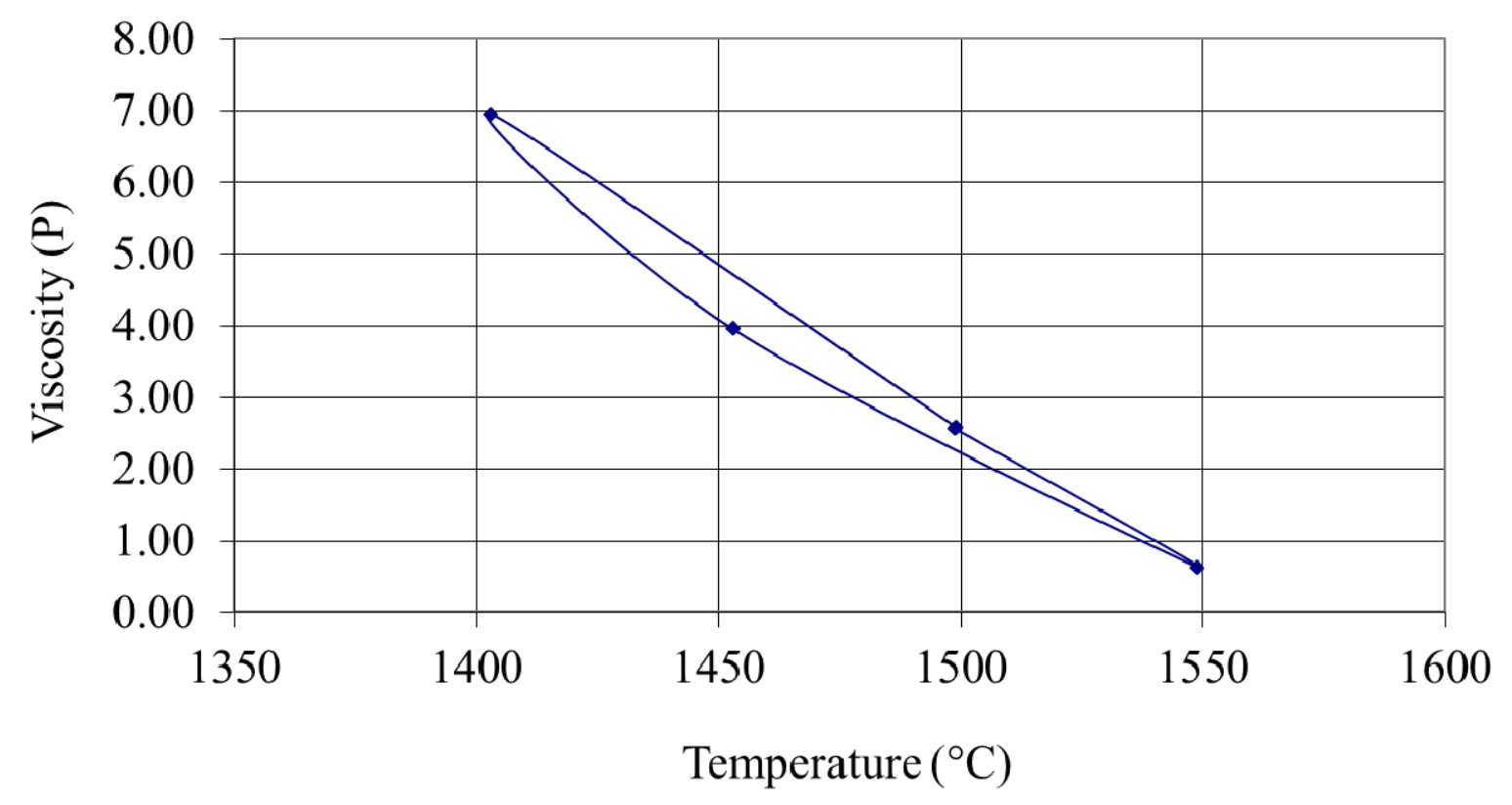

Figure 5-1. Viscosity $(\mathrm{P})$ versus Temperature $\left({ }^{\circ} \mathrm{C}\right)$ for Crystalline Ceramic Waste Form

\section{Path Forward}

Cesium incorporation into single phase hollandite has been achieved with a melt and crystallization process using $\mathrm{Cr}$ transition metal and $\mathrm{Ti} / \mathrm{TiO}_{2}$ bufffer additions to control the reducing conditions. The next step is to include the refined hollandite target phase including $\mathrm{Ti} / \mathrm{TiO}_{2}$ buffer additions as part of the reference ceramic waste form composition. Initial FY13 activities will begin by targeting an alternative waste stream with lower Mo content (3\% instead of $14 \%)$. This new composition will be melted in air, argon and $1 \% \mathrm{H}_{2}$ balance argon atmosphere. The phase formation and secondary phase content will be evaluated with particular attention paid to $\mathrm{Cs}$ and Mo elemental partitioning. In addition to melt processing, alternative fabrication routes are being considered including Spark Plasma Sintering (SPS) and Hot Isostatic Pressing (HIP). This work is part of collaborative activities with Alfred University as part of a DOE-NEUP program on advanced waste forms and the Australian National Nuclear Research and Development Organization (ANSTO). In addition, compositions will be developed and fabricated in FY13 with a new baseline waste stream including TRU actinide elements. The principal goal of FY13 activities remains to demonstrate both the composition and processing for incorporating combined $\mathrm{Cs} / \mathrm{Sr}$, lanthanide, and transition metal (Mo,Zr), and TRU elements into crystalline ceramic waste form with promise of higher waste loading and durability as compared to a borosilicate glass baseline 


\section{References}

[1] Waste Forms Technology and Performance Final Report by National Research Council of the National Academies ISBN-10: 0-309-18733-8, Waste Forms Technology and Performance Final Report by National Research Council of the National Academies ISBN-10: 0-309-18733-8, (2011).

[2] J.V. Crum, L. Turo, B. Riley, M. Tang, A. Kossoy, Multi-Phase Glass-Ceramics as a Waste Form for Combined Fission Products: Alkalis, Alkaline Earths, Lanthanides, and Transition Metals, J. Am. Ceram. Soc., 95 (2012) 1297-1303.

[3] K. Brinkman, K. Fox, J.C. Marra, J. Reppert, M. Tang, J.V. Crum, Single Phase Melt Processed Powellite (Ba,Ca)MoO4 for the Immobilization of Mo-Rich Nuclear Waste, J. Alloy. Compd., Accepted (2012).

[4] A.E. Ringwood, S.E. Kesson, N.G. Ware, W. Hibberson, A. Major, IMMOBILIZATION OF HIGHLEVEL NUCLEAR-REACTOR WASTES IN SYNROC, Nature, 278 (1979) 219-223.

[5] A.L. Billings, K. Brinkman, K.M. Fox, J.C. Marra, M. Tang, K.E. Sickafus, Preliminary Study of Ceramics for Immobilization of Advanced Fuel Cycle Reprocessing Wastes, U.S. Department of Energy Report: FCRD-WAST-2010-000158, SRNL-STI-2010-00560, Savannah River National Laboratory, Aiken, SC (2010).

[6] K. Brinkman, K.M. Fox, M. Tang, Development of Crystalline Ceramics for Immobilization of Advanced Fuel Cycle Reprocessing Wastes, U.S. Department of Energy Report: FCRD-SWF-2011000310, SRNL-STI-2011-00516, Savannah River National Laboratory, Aiken, SC (2011).

[7] K. Brinkman, K. Fox, J.C. Marra, M. Tang, Crystalline Ceramic Waste Forms: Reference Formulation Report Report SRNL Technical Report SRNL-STI-2012-00281, FCRD-SWF-2012-000116, (2012).

[8] V. Aubin-Chevaldonnet, D. Caurant, A. Dannoux, D. Gourier, T. Charpentier, L. Mazerolles, T. Advocat, Preparation and characterization of $(\mathrm{Ba}, \mathrm{Cs})(\mathrm{M}, \mathrm{Ti})(8) \mathrm{O}-16(\mathrm{M}=\mathrm{Al} 3+, \mathrm{Fe} 3+, \mathrm{Ga} 3+, \mathrm{Cr} 3+, \mathrm{Sc} 3+$, $\mathrm{Mg} 2+)$ hollandite ceramics developed for radioactive cesium immmobilization, J. Nucl. Mater., 366 (2007) 137-160.

[9] M.L. Carter, E.R. Vance, H. Li, Hollandite-rich ceramic melts for the immobolisation of Cs, Mater. Res. Soc. Symp. Proc., 807 (2003) 249.

[10] W.J. Buykx, D.M. Levins, R.S. Smart, K.L. Smith, G.T. Stevens, K.G. Watson, D. Weedon, T.J. White, INTERDEPENDENCE OF PHASE CHEMISTRY, MICROSTRUCTURE, AND OXYGEN FUGACITY IN TITANATE NUCLEAR WASTE CERAMICS, J. Am. Ceram. Soc., 73 (1990) 12011207.

[11] S.E. Kesson, THE IMMOBILIZATION OF CESIUM IN SYNROC HOLLANDITE, Radioact. Waste Manage. Environ. Restor., 4 (1983) 53-72.

[12] K. Brinkman, K. Fox, M. Tang, Development of Crystalline Ceramics for Immobilization of Advanced Fuel Cycle Reprocessing Wastes, SRNL-STI-2011-00516, (2011). 